\title{
The Welfare State Within the Context of Liberal Globalisation in Africa: Is the Concept Still Relevant in Social Policy Alternatives for Africa?
}

\section{Tukumbi Lumumba-Kasongo*}

\begin{abstract}
Africans are struggling to reclaim their rights to wealth, liberty, and democracy as mechanisms of articulating social progress. Is the concept of the welfare state still relevant within the existing dominant paradigms of liberal globalisation? In this study, using a historical-structuralist framework, I examine the nature of the arguments about the welfare state. I categorize three types of regimes, namely, social welfare state, liberal welfare state, and transitional democracy and I compare their performances in selected sectors. My main objective is to search for correlative explanations between the ideological foundation of each regime and its social program policy. Based on the data used, it was demonstrated that global liberal democratisation has not yet created any conditions for greater social development and equity in Africa. In all sectors, transitional democracies have performed poorly as compared to other democracies. Liberal democracies have performed lower than social democracies. And social democracies have been systematically ranked higher in the selected social indices. It was concluded that the concept of welfare is still relevant, and thus should provide the epistemological and social basis for rethinking African democracies.
\end{abstract}

\footnotetext{
* Cornell University and Wells College, (New York, USA), and CEPARRED (Côte d'Ivoire).
} 


\section{Résumé}

Les Africains se battent pour la reconnaissance de leurs droits à la richesse, à la liberté et à la démocratie comme mécanismes d'articulation du progrès social. Le concept d'état-providence est-il encore pertinent dans le cadre des actuels paradigmes dominants de mondialisation libérale ? Dans cette étude, en utilisant un cadre historico-structuraliste, j'examine la nature des arguments portant sur l'état-providence. Je dresse des catégories de ces trois types de régimes, notamment l'état-providence social, l'état-providence libéral et la démocratie de transition, et je compare leurs performances dans des secteurs choisis. Mon principal objectif est de chercher des explications corrélatives entre la base idéologique de chaque régime et l'orientation de son programme social. Sur la base des données utilisées, il a été démontré que la démocratisation libérale mondiale n'a pas encore créé en Afrique les conditions requises pour un plus grand développement social et d'avantage d'équité. Dans tous les secteurs, les démocraties de transition n'ont donné que des résultats médiocres comparés aux autres démocraties. La performance des démocraties libérales est moindre que celle des démocraties sociales. Et les démocraties sociales se sont systématiquement montées dans les indices sociaux choisis. Il en est conclu que le concept de bien-être social est encore pertinent et doit donc constituer la base épistémologique et sociale d'une nouvelle réflexion sur les démocraties africaines.

\section{Introduction}

In search of, and in struggle for, building a better African society for the majority of the people, how should Africans reclaim their wealth, their liberty, and their democracy as mechanisms of articulating social progress? As reflected on the existing socioeconomic and political conditions, Africa needs to invent or adopt new paradigms and a new policy base to be able to progress beyond the Millennium Development Goals of 2015. Within the context of both contradictions derived from, and the optimism related to, the dynamics of liberal globalisation defined in a dual-reform framework, namely liberal economics and its laissez-faire and political reform and its liberal democracy, my main objective is to explore how we should adopt and/or create a new form of governance that is humanly democratic, economically productive and sustainable, environmentally friendly, historically and culturally relevant, and which ought to promote gender and social equality in Africa.

Although some historical experiences in African societies are projected into the analysis, this article is more of a critical reflection rather 
than an empirically-based study. In short, I have focused on two related aspects of this work, namely (i) the dynamics of the liberal global context and (ii) the discourse on welfare state and its forms of democracy.

There are three major functioning types of welfare state in the contemporary world, namely (i) liberal welfare states dominated in Western Europe for hundreds of years before the Maastricht Treaty (1992) and the creation of the Euro (2001), (ii) the social welfare states expanded in the Nordic European countries in the twentieth century, and (iii) the ad hoc model welfare state in the United States. The main focus of this article is not about their differences. However, their interpretations of human nature within these political systems are different as well as the origins of the foundation of their ideas, their social agencies, and their embodied visions of society. Thus, they produce different types of societies, democratic processes, citizens' behaviour, expectations, and political participation.

My main objective is not to extend much on historicity of welfare state and policy institutionalisation. I am interested in the welfare state firstly as a political concept. Despite major substantial philosophical, political, and ideological differences between them, conceptually, welfare states do have some common 'ideal characteristics' which focus on democracy. I will examine briefly the origins of the ideas of the welfare state in its limited descriptive manner without claiming its universal acceptability. And I will ask the question of what we can learn from the dynamics of this concept. How is democracy prescribed within the welfare state? Here, I will discuss the core principles of both liberal democracy and social democracy as being part of the welfare state paradigm. And I further examine how these principles and their policy base are reflected in some calculated trends in social and economic indicators using the database of the World Bank.

Many well-intentioned researchers, policymakers, and well-read scholars in social sciences with different ideological persuasions like Claude Ake, Samir Amin, Jagdish Bhagwati, Amiya Kuma Bagchi, Joseph E. Stiglitz, Martha C. Nussbaum, Amartya Sen, Jeffrey Sachs, etc., including those who have advocated the Marshall Plan kind of solution (Stephen 2005; Chollet and Goldgeier 2005-2006) or Tony Blair's approaches, do agree that some types of globalisation can be part of the solution to human miseries and poverty. The question is: What kind of globalisation, based on recent empirical and historical experiences, can genuinely advance human progress, especially in Africa where 'Afro-pes- 
simism' has been rooted in many contradictions of the current dimensions of globalisation policy, politics and development models?

The search for new paradigms that can explain Africa to itself first, its cultures and its socioeconomic and political conditions more effectively and objectively, is the main motivation for writing this paper. Furthermore, despite its dysfunctionality, its apparent incompatibility and lack of innovativeness within its procedures, multipartyism has brought a new energy base and created a new space which can be captured by the progressive or nationalist forces in order to propose an alternative option of the systems of governance in Africa. However, as is well documented, recent political discourse and the functioning of the dominant social paradigm (DSP) reflected in the name of dual liberalism both in economics (free market) and politics (multipartyism) have become the most important factors which led to the acceleration of reversal ideological and political tendencies to authoritarianism and militarism. Recently, these tendencies have developed and manifested themselves in civil wars or violent power struggles, human right abuses, extreme poverty, and wars of invasions in parts of Africa.

The persistence of the deep deterioration of the African conditions (Agyeman 2001) which is reflected in the acceleration of underdevelopment in most parts of the continent and in most social domains are among the important motivating factors for exploring other models of systems of governance. Although this is not my objective in this particular work, it is necessary to recall that we should continue to address the issue of the nature of the causal relations between Africa, its social systems, its cultural diversity, its people, its geo-location, and its contradictory ideological-political foundation. It is no exaggeration to state that despite many efforts by some African social groups, including members of some African political elite, organic intellectuals, working classes, and peasants, all the models of economic organisations and governance have failed to significantly improve the socioeconomic and political conditions of the majority of Africans. Furthermore, the general consensus has been that the contemporary economic reforms in Africa, which descended from the Bretton Woods institutions since the early 1980s which focused mainly on economic growth, free market, and debt, even if and when they had produced limited positive outcomes elsewhere, have not succeeded.

Have the mentioned African conditions, elements of political economy and political culture, and the systems of governance become 
singularly or uniquely unexplained or unexplainable and isolated from the human history, the reason, and the activities of human race? In searching for possible paradigms to analyse the African conditions at large, are Africans themselves operating from the classical logic of trying to 'put all their eggs in one basket' (electoral liberal democracy) or are we using the World Bank's principle of one measure fits all (homogenisation of universal liberal market)?

It is agreed upon that in the past $30-40$ years or so, most parts of Africa have been economically and politically at an impasse. While other parts of the world have economically been growing up in the past decade, Africa is the only continent which has been growing down. What are the main reasons for explaining the nature of this impasse? Is this impasse due to the fact that theories used to analyse and understand the African conditions, the African social and cultural systems, and African people have been irrelevant and inadequate? Is it due to the nature of the weaknesses about, and the lack of imagination of, African political elites, which have been considered in most cases not to be visionaries or are politically uneducated? Is it so because the remedies provided to Africa from the outside have been wrong or unfitted to the African maladies? Is it so because of the implications of the imperatives of structural global conditions on Africa? Or is it so because the international water that Africa has been swimming in has been too polluted or too contaminated with the toxic waste (or acid rain) in its economic and political form?

The issues raised in the above questions have been summarised in Africa Renewal by the assertion of Jeffrey Sachs, UN Secretary-General Kofi Annan's Special Advisor on the Millennium Development Goals (MDGs):

While substantial progress has been made in some regions of the world, 'Africa on the whole has not achieved progress and has experienced significant regress in many areas.' The continent is the epicentre of global poverty, he continued. The reasons for Africa's halting progress are numerous, including poor soils, the effects of climate change and shortages of basic transportation and communications. But these problems have been worsened by the donor community's insistence on market mechanisms, inadequate and poor targeted aid and a tendency to blame Africa. The continent's problems 'cannot be folded under the rubric that poor Africa just doesn't govern itself properly,' Sachs observed. 'Blaming the poor will not solve the problem. Nor is it an accurate, analytical picture' of the obstacles to Africa's development (2005: 5). 
Since African countries gained their nominal political independence, there have been many international, national, and regional declarations, efforts, policies, and foreign initiatives similar to Tony Blair's Commission on Africa, about what should be done about Africa's debts. Some of them were relatively well coordinated and others not so well coordinated depending on their origins and the nature of the actors involved in them. However, it is intellectually and historically undeniable that despite the efforts mentioned above, which were supposedly intended to improve African conditions, high level of political corruption and instability, deep poverty, social desperation, and profound gender inequalities continue to decline in an alarming way. African organic intellectuals and a few of their institutions, social movements, grassroots organisations, and some progressive elements within some civil societies have been searching for new paradigms to deal with the African objective conditions.

Is globalisation real or a myth? How is it functioning? What are its structures and its agencies? What forms have globalisation taken in different parts of the world? What social and cultural values does it represent? What factors internally and externally have shaped it and/ or have been shaped by it? Within the context of the domination of globalisation, its imperatives, policy implications and social consequences, what kinds of values does democracy articulated in a welfare state represent?

Is, for instance, Nicholas Negroponte's plan (he is the chairman and founder of the Massachusetts Institute of Technology's Media Lab) to provide affordable laptop computers for developing communities and do it at a cost of $\$ 100$ each (Staedter 2005) a simple myth? As Staedter reported: 'Negroponte's goal is ambitious. He wants Third World governments to provide one laptop per child in entire regions. Several governments have shown interest. Brazil is expected to purchase one million machines, and China has discussed ordering three million. Additional funding may come from the World Bank and private foundations, Negroponte said' (ibid.).

Although Africa has not manifested interest in this specific project yet (as at 2005), one can speculate about how the global implications of such a project could be in formal education, technological development, and communication in a rural African context, for example.

We have to acknowledge the existence of globalisation in its multidimensional forms in identifying and examining its main characteris- 
tics, attributes, its social and political meanings. This acknowledgement is an intellectual effort to localise the discourse of the welfare state within the existing schools of thought of globalisation at large and within what Bent Flyvbjerg (2001: 134), using Foucault's expressions, has called 'the regular, daily practice'. We have to challenge this acknowledgement both theoretically and empirically in interrogating the global values as proclaimed by theories of liberal democracy. How much financial and economic resources have liberal democratic and social democratic regimes historically invested or spent in social programmes or in human development programmes?

With the rise of liberal democracy or multipartyism since the early 1990s in Africa, despite disagreements among people about its content and how it can be produced and maintained, it is noted that the concept of democracy in itself has become a global aspiring value and an ideal concept. Within the current logic of liberal globalisation and its mandate to further liberalise, privatise, and universalise the market, the concept of liberal democracy has also been seriously challenged in Africa.

Is there any single theory of globalisation that can define more comprehensively and/or more accurately the current African conditions? Probably as discussed later, there isn't such a theory. Then what do all the multiple dimensions of globalisation have in common? Is it possible to produce or to imagine a theory of globalisation that can maintain in its praxis form its global colours or attributes and still be accepted or acceptable locally?

\section{Issues About Globalisation}

Do we live in a global world of illusion or of reality? Historically, we cannot construct a functioning global world without utopia. Within the puzzle called the world of the states, actors have always played different roles to pursue their interests and maintain some equilibrium within the system. Although in the year 2005 social forces and institutions of a functioning world appeared, to a large extent, to be closer to one another in geographical, technological, and selected cultural terms, and in cyberspace politics, in reality, on political and economic grounds, those elements were continuously distancing themselves from one another more than ever in parts of the world. In the past 25-30 years or so the gaps between poor and rich countries and between poor and rich social groups and the political regimes have increased. 
It should be emphasised that there is no single approach that has been philosophically autonomous and self-contained in studying globalisation. Because of its complexity it is imperative that I clarify and also justify my intellectual perspectives, the foundation of my philosophical claims.

What are the substantive meanings of globalisation and their manifestations in different social and political contexts? Although the useful expressions related to various forms of globalisation have been invented and perfected in many languages the world over, the concept is still ambiguous. Its various meanings and multidimensional implications must be located historically within the logic and structures of the geopolitics. Globalisation and its various epiphanies have become the properties of faulty prophets, of demagogue politicians, and of institutions, which claim to be emancipatory or enlightened.

Globalisation means different things to different people. However, no one or state can build a wall around themselves like in the ancient periods in Africa, Asia, and Europe. Autarky cannot be a functionally productive approach. The first atomic bomb that was dropped on Hiroshima and Nagasaki was unfortunately made with the uranium from the Democratic Republic of Congo. About 1.7 billion people as of 2002 (The World Watch Institute 2004), members of the global consumer class, can watch the actual wars through their television sets from their living rooms while they are having dinner. It should be noted that subSaharan Africa's consumer class, the smallest in the world, has just 34 million people while in Japan it is about 120 million and the US and Canada have about 270 million. What does globalisation mean in the daily understanding of the world and in the relationships between the consumer class and other people through wages, labour or products, the Internet, cell phones, and CNN? Democratically, we have the right to know how these products which have become part of our identities are produced. How many parts from various countries of the world are used to make a single car? We also can be inspired by what is going elsewhere. Yet we are related differently to the products we use. What are the living conditions or the quality of life of the people who produce them?

As expanded in this context, globalisation is a movement of goods, ideas, information, services, and political, cultural and economic activities (like production, distribution, and consumption, as well as trade and investment) and their implications at the individual and societal 
levels across political boundaries. At large, globalisation means international integration. Over the years, especially in the twentieth century, this integrative international movement has been accelerated by the power of technology, for instance, the improvement in aeronautic science and technology, the telephone, the Internet browser, etc. Different parts of the world-nation-states and social groupings-have been integrated into the world economy differently. As Charles W. Kegley states: "Globalization is leading to simultaneous integration and disintegration of states, to the growth of some states' power and the erosion of many other states' authority, and global actors know how to adaptively respond to the force of globalization's changes' (2004: 262).

\section{Approaches Within the Existing Perceptions of the World}

Humans embody the germ of the past and build the present on the past. But the past, the present, and the future each has its own specific distinctive moment, space, and time. The present should not sacrifice the past and vice-versa. From this perspective, a social progress agenda is perceived as being essentially a teleological and synthetic conscious effort.

I use a historical-structuralist approach and its philosophical assumptions and claims with a dose of systems analysis as articulated by the advocates of the world system. The way social classes, states, and societies function in the world system is a result of the internal and external dynamics of their locations. But these locations are far from being historically fixed or static. The world is a system and an organic whole, whose behaviour is conditioned by the actors' locations and how they came to be in the system.

One of the most important manifesting characteristics of the world system at the end of the twentieth century was the movement of states and people's struggles to redefine themselves. This redefinition is taking different forms and shapes, some tragically like in the Balkans, many parts of Africa and the Middle East, and others more gradually and peacefully, but the substance of the content of this redefinition and its intellectual quality depends on the dynamics of the local political configurations, how a given people and state have become part of the world system; the location of these actors in the international political economy; what they are bringing into the global market; who the actors 
are; and who their alliances are. This process of redefining themselves is facilitated by the following attributes of globalisation:

i. The level of solidarity, which is being characterised as anti-nation state, among institutions, grassroots organisations, and professional organisations across nation-states, has been increasing. This solidarity is partially due to the relatively high level of consciousness or awareness about the relevant issues. The rising consciousness is the product of the level of interdependence among the actors.

ii. Search for new identities: In most parts of the world people are struggling to redefine themselves by using history and culture, while others are attempting to reconstruct new ideologies or even mythologies through accommodation to the global system. This struggle and processes it creates lead to the various types of clashes of values between what can be or are perceived as the nationalistic values and those which may be considered either as chosen or imposed global values by the global market forces. Since the Westphalia Treaty of 1648 in Europe, the transatlantic enslavement at a large scale, and the colonisation of the world, the common policy of the dominant powers has been to make and re-define national identities in ideological, geo-political and ethnic-linguistic terms protected by the states. Their policies have been the instruments used for systematically weakening individual and collective cultural and ethnic values, as they were often perceived as 'pre-modern' and 'irrational' or primordial forces, the impediments to the building of nationhood.

iii. The nature of new information and communication technologies and the role of the media and the Internet diplomacy in challenging the old national and individual identities and creating new ones in a new international relations context.

iv. And finally, the nature, level, and quality of the world distribution of resources, which are characterised by new opportunities, unequal competition, and social inequality, are essential elements of the discourse of globalisation.

Globalisation is shaped by a multiplicity of actors in world politics. For instance, in 1909, there were 37 officially recognised intergovernmental organisations. By 1994, the number increased to 263. In 1909, there were officially only 176 international non-governmental organisations. And by 1994, the number had increased to 4,928 (Yearbook, 1994/95, pp. 1738-1739). The challenges from multinationals or multilateral and transnational organisations to the state or the centralised authority have obliged the state to make accommodations in order to survive. 
In most cases, the state did not make reforms by its volition. It was forced to do so.

\section{Main Characteristies of the Current Globalisation}

Globalisation is one of the most complex and difficult concepts to define with precision. However, structurally and historically, it is possible to identify its major characteristics and the processes of its reproduction. Globalisation is not new. Why is it that within the existing principles and policies or politics of liberal globalisation, namely the dynamics of liberal economic restructuring and electoral processes, that multipartyism has produced more conflicts and contradictions in Africa than what was anticipated? Is this due to the fact that the African nation-state was built with a birth defect associated with colonial negativism located in the history of the international political economy? I am in agreement with Wil Hout when he states:

The literature on globalization, and possible ways to counter this trend, has unmistakably boomed ever since the end of the Cold War revolutionalized international political and economic relations. Many counts of the causes and consequences of globalization evoke reminiscences of the writings on interdependence that were produced some fifteen to twenty years ago (Jones 1995). Unfortunately, contemporary accounts of globalization share some weaknesses of the interdependence literature, such as the absence of clearly defined concepts, imprecision about causal effects and consequences, and mystifications concerning the overall significance of the phenomenon for international political and economic relations. Moreover, much of the literature on globalization is highly ideological.

In the Penguin Dictionary of International Relations, globalisation is defined as a shift in power relations as follows: 'The process whereby state-centric agencies and terms of reference are dissolved in a structure of relations between different actors operating in a context which is truly global rather than merely international' (1998: 201). David Held et al., define globalisation as 'A process (or set of processes), which embodies a transformation in the spatial organization of social relations and transactions-assessed in terms of their extensity, intensity, velocity, and impact-generating transcontinental or interregional flows and networks of activity' (1999:16). 
The contemporary form of globalisation has its origins in the prenineteenth century capitalist economy. This capitalism was developed in Europe after its inception in the Mediterranean region, not as a national force. After the Industrial Revolution in England, the American Independence Revolution, and the French Bourgeois Revolution, capitalism started to consolidate its global exploitation. That is to say, from the point of view of labour and market, that capitalism was from its inception international with the potential of becoming global. 'Labour for sale' was its motto. It was built on the foundations of a slave economy, of power and class struggles and militarism. As Amiya Kuma Bagchi (1998: 2-3) stated:

Internationally, capitalism evolved as a system of competitive conquest of markets, and sources of labor and raw materials, and arms often decided the conquest. Britain, the first nation to industrialize its economy fully (in the sense that industry provided the major fraction of national income and employment) also became the biggest formal empire the world over has ever seen. In the twentieth century, as the most powerful nation became the top capitalist nation, it also became militarily the most powerful nation on earth. For instance, the military expenditure of the United States as a proportion of global defense spending increased from 30.4 percent in 1985 to 33.3 percent in 1996. Furthermore, the combined defense spending of the United States and the other members of NATO, as a proportion of total global spending, has increased from 50.8 percent to 62.8 percent in 1996.

It should be noted that the movement of global capital started to be slowly consolidated later by enlightenment and liberalism in the eighteenth and nineteenth centuries in Europe as reflected in the writings and political thoughts of Adam Smith, Thomas Malthus, and David Ricardo as they emphasised the doctrine of ethical hedonism (the doctrine that stipulates that ordinary desires were natural and good, not things to be denied or ashamed of), values of individual liberty as a dominant political value and property rights as the foundation of 'rudimentary' capitalism. These grand ideas challenged the system of mercantilism, which prevented the import of most goods from other countries, protected the infant industries, equated wealth with money and judged nations by the balance or size of their balance-of-trade surplus or deficit. Globalisation entered its current global phase after the Second World War when production systems, and even social classes, became trans-nationalised (Ninsin 1998: 25). Since then, the world has 
been bound together by unprecedented volumes of trade, capital, and financial inflows (Amin 1990: 85). As Hilary French also stated:

Growth in trade has consistently outpaced the global economy since World War II. The world economy has grown six-fold since 1950, rising from $\$ 6.7$ trillion to $\$ 41.6$ trillion in 1998. But exports increased 17fold over this period, reaching $\$ 5.4$ trillion in 1998. While exports of goods accounted for only 5 percent of the gross world product in 1950, by 1998 this figure had climbed to 13 percent (2000: 5).

In the past 50 years or so, globalisation has been popularly used to depict the extraordinary scale and intensity of the world's economic transactions, aided by the revolutions in science and technology. Between the 1940s and 1970s, various roles played by the United States government, the United States-based multinational corporations and banks, its military science and technology, its foreign policy, and the modernisation school of thought after the end of the Second World War, were central in the process of defining globalisation. The principles and policies used for the reconstruction of Western Europe after the war with the Marshall Plan (1947), private US banks, the formation of the North Atlantic Treaty Organisation (NATO), and the creation of the International Bank for Reconstruction (the World Bank), the International Monetary Fund (IMF), and the General Agreements on Tariffs and Trade (GATT), testify to the vital role that the United States has been playing in re-conceptualising globalisation. The 'dollarisation' of the world market, followed by 'coca-cola-isation' of the world has been playing an important role in this new globalisation in which the United States has been the major agent. Today, globalisation has reached even the domains of social and cultural aspects of individuals and communities such as arts, popular music and culture, and food as its processes have also been facilitated by the liberalisation of the world economy and financial resources.

Two important aspects of globalisation, which have been projected by the World Bank and the IMF as complementary policy perspectives, are the privatisation of the market and political liberalisation of the public domain. These two dogmas have become the most important forces of globalisation. The rules of the World Bank and the IMF have become the international rules used by the local/national, regional and multilateral financial institutions. Not only have privatisation and liberalisation become global in their content, but the processes of their 
implementations were also intended to produce common or similar effects.

The objectives and the mission of the IMF and the World Bank have already been well defined and established. However, despite the claims of universalism associated with their programmes, their objectives are diversified, and their programmes have not been uniformly adopted at once in all countries as they claimed in the past. They can only be summarised by the following points: to implement measures to stop economic decline and improve the general performance of a country's economy and to assist in assessing budget deficits and imbalances in import/export terms of trade through packages of corrective measures.

Most of the adjustment programmes in Africa and South America, for instance, contain varying degrees of corrective policies focusing on devaluation of the currency, interest rates, reduction of government expenditures to line up with real resources, privatisation, liberalisation, and institutional reforms. Exchange rate policy is supposed to act to devalue currency so that those export commodities can become cheaper and more attractive to foreign buyers. Terms of trade are expected to be fully liberalised and to improve the movement of goods and fiscal policies by removing tax and tariff barriers. And interest rate policies are undertaken to encourage the population to save money and to tighten credit so that people borrow less. The government is encouraged to cut spending on subsidies and other services. In short, adjustment programmes include reforms to:

- Establish a market-determined exchange rate;

- Bring fiscal deficits under control;

- Liberalise trade; and

- Improve the financial sector, the efficiency of public enterprises and the coverage and quality of social services.

Finally, what are the major attributes of the global system? Despite the inconsistencies and incoherence in the ways in which the global system operates, expands and reproduces itself, the world has become a real functioning machine. This system is composed of many different parts and subsystems. But the system is larger than the sum of its parts. For the purpose of this discussion, the following attributes and characteristics of the world can be summarised:

- The growing interdependence and interactions among the actors; 
- An explosion in the number of actors;

- A relatively high level of consciousness about the role of the actors;

- The diminishing classical significance of the meanings of systems of boundaries both at the state and international levels as well as at the personal level;

- A relatively high level of inter-personal and cross cultural relations among people belonging to different orbits of powers and cultures;

- Tendencies toward homogenisation of cultures;

- The weakening of the notion of sovereignty of the state;

- The liberalisation of the market; and

- The privatisation of the state.

From policy points of view, globalisation also means that more and more decisions taken by governments, companies, trade unions, the non-governmental organisations (NGOs), learning institutions, and professional organisations in civil societies, for instance, are influenced by events happening elsewhere in the world.

\section{Liberal Democracy as a Global Phenomenon}

One of the issues to examine here is the meaning of the electoral democracies that have taken place in more than 180 countries. As of 2006, elections have been repeated more than twice in about 122 countries, which are considered as democratic countries. Since the early 1990s, the principles and dogmas of liberal democracy are part of the welfare state equation. In a classical sense, liberal democracy embodies a combination of political rights and civil rights, which go beyond electoral democracy's more limited attachment to civil freedoms and minority rights. What does that mean in a global context after September 11, 2001 ?

After September 11, 2001, when the United States was furiously attacked by very angry young people mostly from Islamic and Arab origins, in the name of national security, new measures and policy articulated by the Homeland Security Agency have been adopted in most countries. These principles of liberal democracy and their values such as individual right, freedom of thought and of religion, freedom of expression and freedom of movement have been seriously challenged. The notion of national security has become more important than that of 
individual right. In fact, the militaristic concept of national security has become global. However, people also have been intensifying their struggles to redefine this democracy and/or appropriate it depending on the local and regional conditions, political history, the dynamics of their culture, and the geo-political location of the actors in the world.

While the adoption of the new security laws and policies by the states are producing on the one hand almost semi-military regimes in terms of their behaviour and policies camouflaged in elections, the people on the other hand have intensified their demands for democracy. Furthermore, despite the decline of party politics among the industrial countries in the past 20 years or so, liberal democracy or procedural democracy has become the dominant play in the opera of world politics. It has become the rule of the game. It has been even attempted by the United States administration to impose it militarily.

One of the difficulties in studying democracy at the global level is that despite the fact that it has become a global desirable end of many social, economic and political pursuits among many peoples the world over, no model of democracy can claim universal acceptability. Different regions, sub-regions, and countries have produced their own democratic experiments. Each democracy among the liberal democratic societies in Western Europe, the United States, and Japan, for instance, has its own technical mechanisms and procedures that define its uniqueness and particularities. People's attitudes, expectations, and responses to democratic institutions, and the nature of the democratic institutions and their values in those countries, also all vary from country to country. However, in a broad sense, for Robert Dahl (1971), democracy can be defined by the following characteristics:

i. an extensive competition among individuals and organised groups;

ii. a highly inclusive level of participation in the selection of leaders and policies;

iii. a high level of civil and political liberties (with all kinds of freedoms); and

iv. it is 'a political system, separate and apart from the economic and social systems to which it is joined' (Diamond, Linz and Lipset 1999:6).

Diamond, Linz, and Lipset refer to democracy as a political system that supplies regular constitutional opportunities for changing the govern- 
ing officials, and that permits the population to influence major decisions by choosing the holders of political offices.

What factors associated with the electoral democracies have been globalised? Have the demands of democracy and the processes of producing democracies become global? Through a new wave of democratisation, democracy has been claimed by most people. Theoretically, the demands have become global.

Although most African countries gained their independence by building or borrowing from the dogmas of liberal democracy and fragile institutions such as chambers or assemblies, in general, for the majority of people the struggle for democracy was not perceived as a political rights issue separate from the overall strategic struggles for total independence. The discourse of self-determination at the international level, which was articulated and promoted by the United States, was essentially adopted in many countries as a national liberation objective or nation-state building dogma. The priorities of most movements and/or political parties that led to political independence in the majority of countries were more on building nation-states and promoting the ideas of constitutional rights and political sovereignty than on procedural democracies and the pursuit of individual political rights. The rights of the nation-state were perceived as more important than those of the citizens.

During the Cold War era, the polarisation of the world by the ideological, military, and power struggles between the Soviet Union and the United States did not contribute to the development of fully fledged liberal democracies. On the contrary, these struggles inhibited it, in controlling the agencies of social changes including the people, in the name of state ideologies and security. Wherever liberal democratic models were introduced, in most situations, they were used as instruments of control and manipulation. In most cases, state apparatuses, especially the ruling political parties and executive branches of government, essentially served as national intelligence agencies for the super-powers to collect information, to recruit, to intimidate progressive forces and to maintain the status quo. Both categories of rights, namely social rights and political rights, which are considered to be the foundation of democracy, were limited and constrained by the dictum of the dominant ideologies. In fact, this international conflict created a non-democratic world, heavily armed and policed by the United States and the Soviet Union and their clients (or cronies). 
Between 1999 and 2000, for instance, there were electoral democracies in about 180 countries. This movement has swept over every region of the globe. In the 1970s, one-party regimes and military dictatorships of various sorts, supported by multinationals, the World Bank and the IMF, the US and the USSR, held power over Africa, South America, Asia, and Eastern Europe.

The new electoral democracies have produced new presidents and members of parliaments or national assemblies. Not only have the claims of democracy become global but democracy is also being perceived and appreciated itself as a global value. There are high expectations about what these electoral democracies should do. Electoral process is being equated to the development process. According to the survey conducted by James Holston of the University of California in San Diego, in 1972 there were 52 electoral democracies, constituting 33 percent of the world's 160 sovereign nation-states. By 1996, the number rose to 118 democracies out of 191 nation-states, or 62 percent of the total, for a net gain of 66 democratic states. Among the larger countries, those with a population of one million or more, the number of the electoral democracies nearly tripled during the same period. Significantly, the number of non-democratic states has declined by a third since the early 1970s, after rising steadily from the beginning of the century. As James Holston stated:

If it took almost 200 years of modern world history to produce fifty democratic states by 1970, it has taken only 10 years of political change since the mid-1980s to yield the same number of new democracies ... In 1975, only four countries in all Latin America had democratically elected national leaders, namely Colombia, Costa Rica, and Venezuela. Of the 36 countries that gained independence in Africa between 1956 and 1970, 33 became authoritarian at the birth or shortly after. The exceptions were Botswana and short-lived electoral democracies in Ghana and Nigeria (2000: 4).

By the end of the 1990s, among 35 states that compose the Americas, for instance, 31 had electoral democracies (89 percent). In South and Central America, of 20 nation-states, only Peru and Mexico would not be clearly considered democratic despite some partial elections. However, Mexico and Peru also had moved away from the list of countries with current tendencies of reversal. In the 1990s, for instance, Botswana, Mauritania, and Nigeria had some important forms of democracy, Senegal, and Zimbabwe had substantive elements of functioning 
multipartyism. Of 53 countries (including Western Sahara) in contemporary Africa, the number of defined electoral democracies increased from 18 percent in 1992 to almost 50 percent in 1999. However, between 1999 and 2005, several democratic reversals have occurred in different periods in countries such as Côte d'Ivoire, Ethiopia, Liberia, Mauritania, Niger, and Sierra Leone. In the Democratic Republic of the Congo, for example, the process of liberal democracy was altogether stopped by the war of invasion. Islamisation of the Sudanese state and the recent movement of Islamisation of the state in Northern Nigeria, for example, are seriously threatening the new electoral democracy. However, as of 2005, there were at least 12 retired presidents in Africa who had completed their constitutional terms and handed over power peacefully after elections (Lumumba-Kasongo 2006). In the Asia-Pacific region, for instance, 24 of its 38 nation-states are now politically democratic (63 percent). Within the new nation-states of the former Eastern Europe, out of its 27 nation-states, 23 have become formally democratic (75 percent).

Although democratic debates and local democratic projects were not absent in the 1990s in the Middle East, it is the only region of the world that was comparatively stagnant in terms of engagement in the pursuit of liberal democracy. Until recently, only Israel and Turkey (14 percent) have had solid formal political debates on democratic and systematic elections and functioning democratic institutions.

\section{The Contemporary Weliare State, Its Claims, and Policy Implications}

Localising the debate of democracy and democratic processes within the context of the discourse of welfare state at large is an important dimension of this article. Thus, in this section I will identify and examine the major characteristics of the welfare state and explore how it defines democracy.

It is the activism of labour parties, socialist/communist parties, leftist groups, and unionists at large that promoted the welfare state. And in a few cases, historically, the imperial regimes' struggles for legitimacy led to the promotion of the elements of the welfare state. There are various views in the ways the welfare state has evolved in its definition, reproduction, its performance, and in its political claims and intellectual arguments. In contemporary societies, these arguments touch more directly on human, individual, or collective rights than in any forms of 
states among the industrial nations. However, the analysis of concrete policies based on the welfare principle needs to be further explored in order to find similarities and dissimilarities among the states advocating welfare programmes. No attempt is made in this section to universalise the characteristics of the welfare state. Its claimed or projected achievements/performances will not be assessed by some universal ethical norms.

In general terms, the concept of the welfare state as practiced in the twentieth century in Western Europe can be defined in terms of the existence of strong or extensive public intervention of the state on behalf of the society or citizens in regulating market behaviour and rules and economic performance and in defining social security and social regulations of the society at large. It also promoted equality between the gender in terms of the job market and distribution of resources. It also tended to subordinate ethnic arguments and regional location over citizenship or social right. In general terms, the welfare state put emphasis on collective developmental or social agenda. Behind this agenda, there was a normative objective of society to be achieved, that is, the 'collective good', or 'common good' or a 'good' society. However, this concept of common good or social good has been better articulated in social democratic regimes than in liberal democratic ones. And social democracy within the social welfare state tends to advance the ideal of 'ontological equality', which articulates that all humans are born equal.

It is argued in this section that the functioning of the welfare state has to be essentially democratic. The welfare state in its contemporary form, whether it is a liberal, nationalist, or socialist/social oriented system in terms of its philosophical foundation, embodies some general elements of 'social' democracy. As Robert Elgie stated: 'The welfare state is more than just a set of static institutions. It takes potent political forces to create and maintain it. In the Western European context, one of the major political supporters of the welfare state has been social democracies' (1998: 78).

Many contemporary nation-states and governments in various periods of their development or evolution have produced various forms of welfare states and programmes to deal with the inclusiveness of their citizens, to address the questions related to social distribution of resources, and to solve social inequalities at a given time. For instance, the formal discussion on the welfare state in India goes back to the writings of Kautilya in his theory of prince as the safeguard of the social 
order based on the Varna and Ashrama system (Kohli 1995:36). In many parts of Africa, the philosophical idea of the welfare state can be located in the notion of traditional 'harmonious' organised or divine cosmology and communal ethos. However, as stated earlier in this section, I am interested in what we can learn from the contemporary debates and policies of the welfare states and not in prescribed science.

Within the current logic of liberal globalisation and its mandate to liberalise, privatise, and universalise the market, the concept of a welfare state has been seriously challenged in many parts of the world, as reflected in recent years in Western Europe and North America. Welfare reforms in Canada and Western Europe were the central issues of debates in the past decade. In developing countries, especially in many African countries, most of the partial welfare programmes associated with the euphoria of national political independence were dismantled as results of various economic crises of the 1970s and 1980s, for instance, indebtedness, inequalities in the market place of the primary commodities, oil crises, mismanagement, etc.

It should be emphasised that many African leaders and their political parties in the 1950s and the 1960s strongly articulated elements of welfare states in their political ideologies such as African socialism, African humanism, Afro-Marxism, African capitalism, and African nationalism including pan-Africanism. To a certain extent, the struggles for independence embodied, in theory, some ideas of making the state the major agency of social change. In addition to the question of the degree and the nature of state intervention, in Africa as well as in Europe, within the perspective of global economic reforms, since the 1980s (with the influences of Reaganism and Thatcherism) there has been a declining interest in the part of the governments to promote and sustain the ideologies of welfare states.

However, it should be noted that the civil societies in many European cities have been waging multidimensional wars against their governments over the question of the welfare state and programmes and the possibility of dismantling them all together based on cost analysis, profit arguments, and free market premises. These struggles, in different forms, are also taking place in popular movements in the developing world.

However, despite the continuous organised global protests in the past several years (1999-2004) from Seattle, Washington, to Washington, DC, Prague, Quebec City, and Paris against policies and politics of the global institutions such as the World Bank, the IMF, the WTO, and 
the summits of the Americas, some scholars argue that this 'war' has, to a certain extent, been partially and legally won by the states with the establishment of the European Union and its common currency, the Euro. Since 2001, the summits of the G-8 have also been meeting vigorous protests by thousands of people who represented hundreds of organisations the world over. The World Social Forum is the most important among the protest movements in terms of the number of people who have been participating in its meetings and its capacity for capturing the attention of the world toward its agendas. Furthermore, the recent rejection of the European Constitution by a referendum in France and the Netherlands is making some governments in Europe rethink the so-called victory of the global liberalisation and the need for re-structuring their welfare state.

The concept of the welfare state in its most current popular usage was born out of the liberal philosophy in Western Europe. It was in the seventeenth century that the philosophy of liberalism appeared in England and it dominated thought in Western civilisation by the late nineteenth and early twentieth century. The paradox is that while European states were pursuing their interests in Africa and other regions through colonisation, in Europe itself the debate on liberal philosophy, which is the foundation of welfare states, was emerging. As Sankhdher and Cranston state:

In explaining the liberal concept of the welfare state in England during 1889 and 1914, we should begin by a precision of its symbolic representation at the point of culmination in Lloyd George's mind. The Liberal philosophy, which had its origin in John Locke's ideas, was given a new turn by the philosophical Radicals and the Utilitarians. In practical politics, however, liberalism in this period, though rooted in individual liberty, extended the meaning of liberty to incorporate the idea of welfare state (1985: 245).

Thus, political representation as the key characteristic of liberalism has been one of the most important forces of welfare state. After the French and industrial revolutions, the attributes of liberalism were expanded from individual quest for freedom to societal struggle against "undemocratic parliaments' and despotic monarchs. Of course this was not done without bourgeois power struggles and proletarian struggles as well. As stated earlier in the nineteenth century, both classical liberalism and later Marxism were distrustful of the state. The classical state was conceived as an instrument of coercive forces and thus it was perceived as 
anti-individualism. In England, liberalism was articulated by such philosophers as Edmund Burke, Herbert Spencer, T.H. Green, William Berridge, J.M. Keynes, Ludwig von Miesse, etc. They were against the exercise of unlimited power by the state and monopolistic law of capitalism. Thus, the main characteristics of liberalism include: the ideology of representative democracy, based on the Rule of Law, the notion of limited government, and the concepts of individual's rights of life, liberty and property (Sankhdher, op.cit., 1985: 245). As Mimi Abramovitz said:

Classical liberalism originated in seventeenth-century England, took root in the eighteenth century, and with the rise of industrial capitalism, became the dominant political theory of twentieth century Western societies. Reflecting new views of human nature which placed selfness, egoism, and individualistic self-interest at the center of human psyche, liberalism held competitive pursuit of individual self-interest in a market free of government regulation would maximize personal and societal benefits (1989: 14).

Struggles against the feudal economies, monarchical and strong states in their militaristic and personalised forms contributed to the creation of the welfare states in Europe. The industrial revolution of the 1700s and early 1800s led to the development of social insurance in many parts of Europe as most of the workers received low wages and were also working under hazardous conditions. Thus, many workers did not or could not afford to live a relatively productive life. For instance, in 18831889, Germany was the first nation-state in Europe to institute national welfare programmes and mandatory workers insurance. Chancellor Otto von Bismarck, who instituted the welfare programmes, was trying to accomplish two objectives: (i) to remove the workers' impetus for organising a possible revolution (or a revolt) and (ii) to ensure that the cost burden of the programmes would not be borne by the local governments. Even during the years leading to the Second World War, social welfare programmes continued to expand, as it is stated in Article 20 (1) of the Basic Law that Federal Republic of Germany is a 'democratic and social federal state'. The nature of the relationship between other nations has partially been determined by the effort of the government to provide the basics for all Germans. As Krasner indicates:

In addition to attempting to control the flows of capital and ideas, states have long struggled to manage the impact of international trade ... Depression and plummeting grain prices made it possible for German 
Chancellor Otto von Bismarck to produce the landholding aristocracy into a protectionist alliance with urban heavy industry (this coalition of 'iron and rye' dominated German politics for decades) (2001: 24).

In France also since the pre-revolutionary times, entrepreneurial timidity was partially compensated for by the role the French government played in technological innovations and economic development as indicated by Henry W. Erhamm (1996) that the royal fermiers, JeanBaptiste Colbert's mercantilism, and the way in which Napoleon III's entourage interpreted the doctrines of Claude-Henri Saint-Simon, created the traditions. As Britain's Keith Windschuttle (1999) stated:

The reforms Bills of 1867 and 1884 extended the franchise to males in virtually all social classes. The new concept of the state sanctioned the existing political parties to abandon laissez-faire and to appeal to these new voters with the promise of social legislation and welfare reform. Whereas classical liberal regarded the state as necessary evil, the new liberalism saw the state as a necessary good that was capable of removing or alleviating the insecurities and misfortunes of newly enfranchised lower orders. It was the Liberal Imperialist governments of 1906-16 that went furthest in delivering tangible legislation to back these ideas: the Workmen's Compensation Act of 1906, the Old Age Pension Act of 1908, the Minimum Wage Act of 1909, and the National Insurance Act of 1911 . The welfare state of the later twentieth century was largely an unfolding of principles and measures introduced in these years (pp. 8283).

The welfare state in the twentieth century was also characterised by the principle of limiting constitutionally the power of the governing political elite. It also promoted the intervention of the state on behalf of individuals to create the conditions that should allow the individual the ability to maximize self-interest and to secure liberty, equality, and justice. Most of the welfare programmes or packages that were produced in Western Europe include laissez-faire doctrine that restricted the responsibilities of the state without eliminating its regulatory role as protector of capital, property, and national security (Abramovitz 1989: 15). Pragmatically, Sankhdher and Cranston describe the welfare functions as follows:

The key functions of a welfare state were, in addition to police responsibilities, promotion of economic development and social welfare by providing full employment, equal opportunity, social security and insurance of a minimum standard of living for those downmost of the 
social ladder. Such an idea materialized largely in the Beveridge plan which prescribed, within a liberal democratic framework, provision of basic needs, and also remedies for problems of disease, ignorance, squalor, and idleness. It was the application of collectivist methods for the individualistic aims of laissez-faire (1985: 246).

The idea that the government ought to protect minimum standards of income, nutrition, health, housing, and education assured to every individual as a political right, not as charity (Abramovitz 1989: 16), can be generalised as the universal claim of a liberal political thought. Within the Marxist traditions, the welfare state is to use the state power to modify the reproduction of labour power and to shift the costs of socialising and maintaining workers from the private capital to the public sphere (p. 17).

The concept of justice that has been the philosophical and social engine in welfare states can be summarized in the following statement of John Rawls:

Justice is the first virtue of social institutions, as truth is of systems of thought. A theory however elegant and economical must be rejected or revised if it is untrue; likewise laws and institutions no matter how efficient and well-arranged must be reformed or abolished if they are unjust. Each person possesses inviolability founded on justice that even the welfare of society as a whole cannot override. For this reason justice denies that the loss of freedom for some is made right by a greater good shared by others. It does not allow the sacrifices imposed on a few are outweighed by the larger sum of advantages enjoyed by many. Therefore in a just society the liberties of equal citizenship are taken as settled; the rights secured by justice are not subject to political bargaining or to the calculus of social interests (1971: 3-4).

In addition to legalism, other related notions developed in the welfare states are those of equal citizenship and equal participation in the political affairs of the states. The liberal theory of politics allows social changes through legalistic reforms with the focus on individual rights. But not all legalisms can promote social justice as Alan Wolfe said in the case of the ad hoc welfare of United States. For instance:

America's failure to contemplate, let alone redress, social injustice and inequality is another indication of its impasse, a backhand confession that ills are beyond the reach of human action to remedy them. For a 'can do' culture, such an intimation of impotence was found relatively easy to accept (1989: 81). 
A selective approach to welfare programmes puts the case of the United States neither on the liberal crusade against injustice nor on a standpath preference for the status-quo especially during the New Deal era (Wolfe 1989). But the social cost in choosing this approach has been heavy with the long-term impact that is extremely difficult to deal with for many generations in the era of globalisation. The principle of each according to her/his merit has retarded the discourse on the pursuit of social equality, including the gender relations in the United States. The major distributive principle that socialists used was 'each according to her/his needs'. Whether factually all socialist welfare states or welfare states within social democracies attempted to transform the social relations can be questionable, their theoretical principle of each according to her/his needs is worth pursuing.

Comparison of Selected Social Indicators within Liberal, Social, and Transitional Democracies

I am not interested in identifying causal relations between social indicators and the nature of democracies representing different types of welfare. However, I am interested in making correlative comments between democracies and social indicators. In the principle within the framework of welfare states, all democracies should be concerned with social policy issues, totally or partially. Thus, the major differences among them can be described in terms of the centrality of social policy in a given government and regime, and its importance in determining statesociety relations, and in the way social policy is institutionalised and systematised. As Michael Newman states:

'Social Policy' is a term that may be defined precisely, and the EU has used it to cover a wide range of issues, ranging, from apparently technical 'health and safety' matters to 'quality of life' concerns, to much more politically sensitive areas, including industrial relations systems, and retributive policies covering health, education, housing and social security (1996: 77).

In the final dimension of this study, I am trying to capture comparatively in figures some aspects of the performance associated with, and/ or spending patterns of, the types of groups of democracies articulated within welfare states at large examined in this work.

As discussed earlier in this work and also below, though the essence of this analysis is reflective, some general comparative criteria are used 
to help contrast policy implications of the selected types of democracy. I should reiterate that the main objective here is not to find causal relations between democratic practices and their policy formulations and implementations but rather, to explain correlations and implications between the dogmas of three selected types of democracy and their performances. For the sake of this generalized theoretical reflection, a few selected criteria for categorizing democracies are considered. They are not historically fixed. Nor are they considered perfect and automatically verifiable all the time. The possible actualization, appreciation or measurement of these criteria varies from one regime to another and from one society to another. However, these criteria can be found and identified in all practical democracies in terms of political goals, political organization, and societal expectations. These criteria include the degree of: $(\mathrm{A})$ regularity of the elections $(\mathrm{B})$; the legal guardianship of elections; (C) stability of political regimes; and (D) the social foundation of the outcomes of the electoral process.

Based on studies of comparative constitutions (for instance, Lumumba-Kasongo 2005), in general, liberal democracies are categorized as having higher level of A, B, C and less for D than other types of democracies. Liberal democracies tend also to emphasize individual rights, individual liberties and merits, legal procedures, and political representation. Social democracies embody all the above criteria and also a special emphasis on social and collective rights and programmes, distributive justice, and public interests. Transitional democracies are relatively new. Thus, they tend to be less stable in their functioning and less predictable in terms of the feasibility of their actions. However, though at a lower level, they also embody some aspects of A, B, C and $D$. It should be noted that there are vast differences in practice among the liberal democracies, for instance between the United States' model and the European ones. Furthermore, the countries with transitional democracies also tend to have more differences among them because of lack of, and/or weak, political culture of democracy, less legal guardianship of the electoral process, and the high level of political amateurism vis-à-vis the respect to democracy and its values. The social foundation of democracy is weakest in the transitional democracies because of combined factors such as the level of economic underdevelopment, the low level of education, and «impracticability» of the existing forms of democracies. For further information about the behaviours of the transi- 
tional democratic regimes in Africa in relationship to elections, see my article (Lumumba-Kasongo 2007).

The lists of the countries selected are:

- Selected Liberal Democracies: Australia, Belgium, Canada, France, Germany, Japan, Netherlands, United States, Spain, and Italy.

- Selected Social Democracies: Sweden, Switzerland, Denmark, Finland, and Iceland.

- Selected Transitional Democracies: Algeria, Côte d'Ivoire, Demo-cratic Republic of Congo, Egypt, the Gambia, Ghana, Kenya, Mozambique, Nigeria, Senegal, and South Africa.

It should be noted that my choice of the countries selected in this section is generally personal. It is mainly due to my own areas of interest, the visibility of the countries in either the struggle toward democracy, the deepening of the crisis of democracy, or the positive evolution of democracy. What is important is to have a certain degree of representation in comparing governmental expenditures as they can inform us about either policy priorities or their possible commitment to respond to people's needs. I believe that the patterns of expenditures may inform us about responsibility of the governments, their commitment toward the improvement of human conditions and human and social rights.

The following selected sectors were incorporated in the study: (a) Education; (b) Health; (c) Agriculture; (d) Employment/Unemployment. The main source of the data used in this section is the World Bank, World Population Data Sheet 1999-2003, (Washington DC, Population Reference Bureau, World Bank).

It should be noted that comparatively proportional percentages of expenditures by GNI, GDP or GNP reflect only the total amount of money in a given country. Percentages of spending in a given sector in Côte d'Ivoire, for instance, have different significance than percentages of spending in the same sector in Japan or the United States. The size of the economy and the size of population are important variables that should be taken into account in understanding the significance of the figures elaborated in this section.

The differences in the proportions of GNI, GNP, or GDP that countries allocate to their respective social services in general do not reflect the actual amount of money, in raw numbers, that these countries 
have for these services. Indeed, the total amount of money available for public spending is a reflection of each country's GNI, GNP, or GDP. For instance, even with a higher proportion of its GNI allocated to the health care services, a poor/developing country typically has a much smaller amount of money than an industrial country with a lower percentage of GNI allocated to its health care services. And yet, the needs for investment in heath care services are much greater in a poor country.

Table 1: Education Expenditure (\% of GNI), 1970-2003

\begin{tabular}{lccc}
\hline & Africa (TDs) & Liberal Democracies & Social Democracies \\
\hline 1970 & 3.67 & 4.52 & 4.97 \\
1980 & 3.91 & 5.25 & 5.68 \\
1990 & 4.21 & 4.81 & 5.73 \\
2000 & 3.87 & 4.53 & 6.46 \\
2003 & 3.87 & 4.55 & 6.45 \\
\hline
\end{tabular}

As reflected in Table 1, while in every ten years since 1970 education expenditure in percentage terms of GNI has increased in social democracies, with relative slowing down between 1980 and 1990, in liberal democracies it has been constantly decreasing and it stabilised between 2000 and 2003. With the exception of 1990, where Africa reached an increased percentage of 4.21 less only 0.60 percent from liberal democracies, it has lagged significantly behind other democracies.

In the same periods, 1970-2003, Africa (transitional democracies) spent a higher percentage of money allocated to education in the tertiary sector by student, about 56 percent; then comes the social democracies with about 45 percent, and last are the liberal democracies which spent about 30 percent. When it comes to secondary education, both social democracies and liberal democracies spent approximately the same by student, 43 percent and 41 percent respectively. And the transitional democracies spent less than the above with only about 18 percent. In elementary education, the same trends continue to be reflected with social democracies spending about 21 , liberal democracies 18 , and transitional democracies about 12 percent by student. Although these figures do not tell much about the real distribution among various social groups, they reflect general trends in spending. 
In the health sector, the figures of vaccinations of DPT and measles of infants (age 12-28 months old), for instance, combined with those of the infant mortality may also reflect the quality of the services that political regimes have provided at a given time. Although we do not have sufficient information about how much the regimes have effectively spent in different health and health-related sectors, the access to vaccinations is an important policy item as it deals with the future of the society, the children. It should be noted that percentages of the children vaccinated in the transitional democracies, liberal democracies, and social democracies have all been increasing. However, the percentages of the infants vaccinated have been consistently higher in social democracies than in liberal democracies. Although the percentages are also increasing in the transitional democracies in Africa, they are significantly lagging behind both liberal democracies and social democracies.

Table 2: Immunisation DPT (Diphtheria-Pertussis-Tetanus) and Measles (Percentage of children ages 12-23 months): 1980, 1983, 1990, 2000, and 2003

\begin{tabular}{lccc}
\hline Immunisation & Africa (TDs) & Liberal Democracies Social Democracies \\
\hline I980 & & & \\
DPT & 42.33 & 76.50 & 93.75 \\
Measles & 36.00 & 67.75 & 88.00 \\
1983 & & & \\
DPT & 45.00 & 86.71 & 94.20 \\
Measles & 47.00 & 55.67 & 83.75 \\
1990 & & & \\
DPT & 65.82 & 90.30 & 93.17 \\
Measles & 66.45 & 80.30 & 92.17 \\
2000 & & & \\
DPT & 69.73 & 93.00 & 97.00 \\
Measles & 70.18 & 89.50 & 91.50 \\
2003 & & & \\
DPT & 72.27 & 94.40 & 95.67 \\
Measles & 71.73 & 90.90 & 91.00 \\
\hline
\end{tabular}

Access to health services is a societal and state responsibility. It is expected that citizens' health or the health of the society at large ought to be considered as an important factor in assessing the meaning of any 
Table 3: Health Expenditure in 1998, 2000, 2002. 2003

\begin{tabular}{lccc}
\hline Category & Africa (TDs) & Liberal Democracies & Social Democracies \\
\hline 1998 & & & \\
Public & 3.36 & 2.80 & 6.54 \\
Private & 1.95 & 6.17 & 1.96 \\
2000 & & & \\
Public & 3.20 & 2.82 & 6.52 \\
Private & 2.20 & 6.28 & 1.95 \\
2002 & & & \\
Public & 3.19 & 3.00 & 7.25 \\
Private & 2.40 & 6.62 & 2.09 \\
2003 & & & \\
Public & 3.36 & 2.80 & 6.54 \\
Private & 1.95 & 6.17 & 1.96 \\
\hline
\end{tabular}

democracy. Health is a social right. Obviously, it implies that a healthy population should be happier, more productive, innovative, engaging, and ready to support the state's programmes and policies.

The figures in Tables 2 and 3 are consistent in the three different periods, 1998, 2000, and 2002 used in this research. In 1998, for instance, the percentages of the public expenditures in the transitional democracies and social democracies were higher than those in the liberal democracies, 3.36 and 6.54 as compared to 2.80 respectively. Even the developing countries in Africa, with very poor infrastructures and higher medical demands and costs, have been able proportionately to spend more in the public health sector than the liberal democracies. The private health expenditures in the transitional democracies were almost equal to those in social democracies. It should be noted that the private health expenditures in liberal democracies are almost the same percentages as those of social democracies in the public sector. In Africa with the recent privatisation of health services, the gap between the expenditures in private and public health is gradually diminishing. Social democracies spent more than 70 percent of the money allocated to health in the public sector while liberal democracies spent more than 65 percent in private health services. In Africa, although the public health 
expenditures are still slightly higher, the gap is closing between the public and private expenditures.

Table 4: Female Adults with HIV (\% of Population Aged 15-49 with HIV)

\begin{tabular}{lccc}
\hline & Africa (TDs) & Liberal Democracies & Social Democracies \\
\hline 2001 & 48.77 & 22.9 & 24.89 \\
2003 & 49.79 & 23.71 & 24.57 \\
\hline
\end{tabular}

Table 5: Prevalence of HIV (\% of Population Aged 15-49)

\begin{tabular}{lccc}
\hline & Africa (TDs) & Liberal Democracies & Social Democracies \\
\hline 2001 & 5.7 & 0.31 & 0.18 \\
2003 & 5.13 & 0.32 & 0.18 \\
\hline
\end{tabular}

Table 6: Female Employment by Sector in 1980

\begin{tabular}{lccc}
\hline Category & Africa (TDs) & Liberal Democracies & Social Democracies \\
\hline Agriculture & 67.81 & 14.81 & 6.50 \\
Industry & 5.38 & 20.89 & 18.8 \\
Service & na & 70.7 & 74.58 \\
\hline
\end{tabular}

Table 7: Total Female Employment in 1990

\begin{tabular}{lccc}
\hline Category & Africa (TDs) & Liberal Democracies & Social Democracies \\
\hline Agriculture & 69.56 & 11.90 & 3.95 \\
Industry & 5.70 & 17.28 & 15.15 \\
Service & 24.70 & 77.76 & 80.80 \\
\hline
\end{tabular}

While the transitional democracies have almost double the general percentages of females with HIV, social democracies have slightly higher percentages than those of liberal democracies. However, within the total population, the transitional democracies have a very high percentage and the lowest are social democracies.

It is argued that employment is an important aspect of security protection, personal growth and social development. From a citizen's point of view, it is a democratic right. In this specific work I am not interested 
in what kind of job was provided. However, these tables should inform us about what sector has the higher percentage or less employment. Furthermore, gender equality is an issue in all democracies.

Females have been, in most contemporary societies, marginalised by policies and politics of some regimes based on men's cultural dispositions and political ideologies of domination. The way a given political regime or society at large treats girls and women in the public sector is very much a reflection of the quality of such a system. A democratic system is a system that does not discriminate against anyone based on gender, social and national, or religious origins. Here I examine only the general patterns of the employment distribution in percentages in the agriculture, service, and industry between men and women.

In 1980 in Africa, the agricultural sector employed more than 60 percent of all workers, a trend that can be generalised in all other years. The industrial sector was the smallest area of employment with only 17 percent while the service sector represented about 23 percent. It is interesting to note that in both liberal democracies and social democracies almost 58 percent of employment was located in the service sector, about 34 percent in the industry, and only 8 percent in agriculture. The percentages of the distribution of employment in all three sectorsservice, industry, and agriculture-are almost the same in both liberal democracies and social democracies.

When it comes to the gender distribution in these three sectors in 1980, in Africa about 90 percent of women's employment was in the agricultural sector and only 8 percent in the industry. Data were not available in the service sector. In both liberal democracies and social democracies, women's employment in the service areas was much higher than in other sectors, with almost more than 70 percent as indicated on the table of female employment. The only significant difference is in the area of agriculture with 14.81 percent of women in the agricultural sector in liberal democracies while it was only 6.50 in social democracies. The similar trends of female employment among the transitional democracies, liberal democracies and social democracies are reflected in the 1990s with the difference that female employment in social democracies significantly increased in the service sector to 80.80 percent as compared to 77.76 percent in liberal democracies. And the decline in the agricultural sector of women's employment is orchestrated with 3.95 percent as compared to liberal democracies 11.90 percent. 


\section{Concluding Remarks}

It is argued that Africa will not produce any kind of genuine democracy within the existing socioeconomic conditions. Extreme poverty, which accompanies African economic reforms, does not or will not promote democracy. The situation is characteristic of what W. Alade Fawole (2005) has called: 'Voting without Choosing'. Recently, these kinds of elections in Africa have been creating a high level of violence in countries asuch as Ethiopia, Niger, Uganda, Tanzania (Zanzibar), Zimbabwe, etc. Furthermore, political space in Africa is a space of intense contest, an area in which the so-called opposition parties and the declared ruling parties are struggling mainly to gain access to material resources and not necessarily for articulating good governance.

Global liberal democratisation at the general level has not yet created any conditions for greater social development and equity among the majority of the African population, the primary aim of real democracy. Despite the rise of multipartyism, there is a high level of decline of citizen loyalty to the African state. The size of the gray space where state and citizens should meet and negotiate has significantly decreased. In most cases in Africa, electoral processes have been far from producing democracies. That is to say that many new proclaimed procedural democracies have not been able to convert global resources to satisfy domestic policies, job market, and the basic needs because within the framework of liberalisation and privatisation, the African states become literally the agencies of the multinationals rather than being the agencies of people's social protection. Thus, these states are losing the basis of their legitimacy and sovereignty. Within the existing paradigms of political pluralism, it has become clear that what is good for the market is not necessarily good for individuals and people.

It is clear that socially defined welfare states, until recently in Northern Europe, had a strong base for a collective citizenship perspective in dealing with the social needs and progress in contrast with the liberal democracy in the United States. In this case, individual rights and personal hard work ethic (the Weberian Protestant Ethic) are promoted as the most important means to social progress.

Although resembling other democracies, African transitional regimes are not all the same and do not exhibit the same kinds of behaviour in the circulation of power, the formulation and implementation of policies, or in the way people participate in them. Their political institu- 
tions are still relatively new and fragile. However, they also have tendencies to monopolistic ruling parties. The rules of political games and the outcomes of the politics discourse are still less democratically predicted or predictable. And their political culture and civil societies are not sharply independent from the rules and dictum of the state power.

In short, in all sectors, transitional democracies have performed very poorly as compared to other democracies. At large, liberal democracies have performed lower than social democracies. And social democracies have been systematically ranked higher in the social indices used in this work.

In short, global capitalism has created a global apartheid system which consists of 'the established centres (European Union and NAFTA), the emerging peripheries (East Asia, South Africa), struggling peripheries (much of Latin America and the Middle East), and stagnating peripheries (much of the Sub-Saharan Africa)'. The bulk of global resource flows is confined to the dominant capitalist centre. According to Keet (1997:23):

Fully $84 \%$ of all Foreign Direct Investment (FDI) originates within such countries, with a large proportion (of almost 40\%) originating in just two countries, the USA and the UK, in $1996 \ldots$ (A)lmost $60 \%$ of global FDI in that year was still moving between the most developed industrialized countries of North America and Europe ... 98 out of the 100 largest TNCs, globally, originate in the OECD ... Fully $87 \%$ of all TNCs are headquartered in the EU, the U.S., and Japan; and in 1996, 88\% of their 'foreign assets' were actually located in each other's economies.

While many African countries have produced new elected governments and parliaments, the level of poverty has increased. In early 2000, for instance, it is estimated that there were more than 1.3 billion poor in the world and that 13 to 18 million die annually of poverty-related causes. The population of Africans living below $\$ 1$ a day was 44.6 percent in 1990 but rose to 46.4 percent in 2000. Resources are concentrated in the hand of fewer people, countries, and companies. For example, the African continent's share of the Foreign Direct Investments (FDI) which goes to the developing world has declined from an average of 15 percent in the 1970s to 10 percent in the 1980s, and to just 5 percent by the mid-1990s. Its share of global trade has also declined from 3 percent in the 1950s to barely l percent in 1995 (ibid.). While East Asia alone accounts for a quarter of total world trade (UNCTAD 1998: IV), Africa's exports shrank from 5.3 percent in 1950 to 1.5 
percent in 1995, and her imports from 5.7 percent to 1.7 percent during the same period (ibid. 183).

In the search for democracy in Africa, vital issues of social and collective rights should be redefined and introduced in the debates of the existing framework of the electoral democracies. I am claiming that global liberal democratisation alone, in the way it is functioning now in terms of people's rights to elect their leaders, will not solve the problem of poverty in Africa. In fact, in many transitional democracies, which function under the imperatives of transnational corporations, certain types of 'autocratic multipartyism' have started to replace practices of liberal democracy, especially in relationship to the imperative of new security apparatuses.

I argue that limited political rights that Africans have gained in the struggles for global liberal democratisation will not be fully actualised and expanded until people also collectively gain their cultural and economic rights. That can be done either through social revolution, political and social reforms and activism, or massive political participation.

Democracy would be actualised if Africans first reclaim the states. The reclaiming is the process of transforming the state from within itself. It is through political education, human investment, political participation, and social movement that this reclaiming can be examined and actualised. Africans are capable of producing a globalisation that can have a human face; that is, one that may embody the following values: collective social justice for all, respect for diversity, an environment-friendly technology, and gender equality in the distribution of resources.

Finally, my perspective of democracy is reflected in the following quotation:

Democracy is not a menu prepared from the outside of a given culture. It is a political means through which social contradictions, with respect to collective and individual rights, should be solved at a given time and in a given society. There cannot be real democracy if a concerned society does not have any consciousness of its own contradictions, does not allow political debate, and does not outline a social practice to provide rules for the society to manage its interests and objectives with equity and justice. Democracy should be a struggle against social inequality, injustices, exploitation, and social miseries. That is to say, democracy is more than formal political pluralism or the process of producing an electoral code or an electoral commission ... Democracy is both a process and a practice that involves equal economic and social opportunities for 
the citizenry. It is a corrective process in which a given society, especially a formerly colonized society, is born again (Lumumba-Kasongo 1998: 34).

In my view, the concept of welfare is still relevant, and thus should provide the epistemological and social basis for rethinking African democracies. It is only in a social welfare state that the kind of democracy described above can be fully actualised. The social welfare state has mechanisms for promoting genuine dialogues with all the segments of the society through social programme agencies and partnerships between the government, the society, and private corporations. It is characterised as being a highly inclusive system. In search of African models of development, it is necessary to articulate a state in which the concept of public good can also benefit from the benevolence and profitability of critically defined and socialised private corporations. This state should have as its priority to meet the basic needs of all its citizens. Within the context of these reflections on Africa's welfare state, the concepts of prosperity and good life should be redefined to encompass: the basics for survival, including food, shelter, and a secure livelihood, good health, social cohesion, and political freedom (OECD: The Well-being of Nations 2001).

\section{Acknowledgement}

I would like to thank my former Teaching Assistant (TA) and Advisee Maeve Kristen Powlick, a Ph.D. candidate in Economics at the University of Massachusetts at Amherst, who helped with the data collection, the calculation of percentages, and the making of the tables.

\section{Reierences}

Abramovitz, Mimi, 1989, Regulating the Lives of Women: Social Welfare Policy From Colonial Times to Present, Boston, MA: South End Press.

Agyeman, Opoku, 2001, Africa's Persistent Vulnerable Link to Global Politics, San Jose, New York, Lincoln, Shanghai: iUniversity Press.

Africa Renewal, 2005, 'Small Steps Can Make a Big Difference: Achieving Millennium Goals in Practical Investments', January, Vol. 18, No. 4.

Amin, Samir, 1990, Maldevelopment: Anatomy of a Global Failure, London, Zed Books Ltd., and United Nations University Press.

Baaklini, Abdo, Guilain Denoeux and Robert Springborg, 1999, Legislative Politics in the Arab World: The Resurgence of Democratic Institutions, Boulder: Lynne Rienner. 
Bagchi, Amiya Kuma, 1998, 'Globalization with Equity, Policies for Growth’, (Synthesis Report), mimeo, Manila, ILO, SEAPAT.

Burnell, Peter and Vicky Randall, 2005, Politics in the Developing World, New York and Oxford: Oxford University Press.

Chollet, Derek and James M. Goldgeier, 2005-2006, 'The Faulty Premises of the Next Marshall Plan,' The Washington Quarterly, vol. 29, part 1 (Winter).

Dahl, Robert A., 197 1, Polyarchy: Participation and Opposition, New Haven, CT: Yale University Press.

Diamond, Larry, Juan J. Linz, and Seymour Martin Lipset, 1995, Politics in Developing Countries, Comparing Experiences with Democracy, London and Boulder: Lynne Rienner.

Elgie, Robert, 1998, 'Democratic Accountability and Central Bank Independence: Historical and Contemporary National and European Perspectives', Western European Politics, Volume 21, Number 3 (July).

Erhamm, Henry W. and Martin A. Schain, 1992, Politics in France (Fifth) Edition, Harper Collins Publishers.

Evitsky, Steven and Way, Lucan A., 2002, 'The Rise of Competitive Authoritarianism,' Journal of Democracy, Volume 11 Number 2: 51-65.

Fawole, W. Alade, 2005, 'Voting Without Choosing: Interrogating the Crisis of 'Electoral Democracy in Nigeria'. In Tukumbi Lumumba-Kasongo (ed.) Liberal Democracy And Its Critics in Africa; Political Dysfunction and the Struggle for Social Progress, London, Zed Books, Pretoria, UNISA Press, and Dakar, CODESRIA.

Flyvbjerg, Bent, 2001, Making Social Science Matter: Why Social Inquiry and How It Can Succeed Again, Cambridge: Cambridge University Press.

French, Hilary, 2000, Vanishing Borders: Protecting the Planet in the Age of Globalization, New York: W.W. Norton and Company.

Graham, Evans, and Jeffrey Newnham, 1998, The Penguin Dictionary of International Relations, Harrmondsworth: Penguin.

Gwynne, Robert N. and Cristóbal Kay, 2004, Latin America: Transformed Globalization and Modernity, New York and London, Oxford University Press.

Held, David, Anthony McGrew, David Goldblatt and Jonathan Perraton, 1999, Global Transformation-Politics, Economics, and Culture, Cambridge, England: Polity. Press

Holston, James, 2000, 'Urbanization Citizenship and Globalization', Paper delivered to the International Studies in Planning Program, Cornell University, the Department of City and Regional Planning, Ithaca, New York, April.

Hout, Wil, 1997, 'Globalization and the Quest for Governance', Mershon International Studies Review, Volume 41, No. 1, May: 99-106.

Jones, R.J. Barry, 1995, Globalization and Interdependence in International Political Economy: Rhetoric and Reality. London and New York: Pinter.

Keet, Dot, 1995, 'Integrating the World Community: Political Challenges and Opportunities for Developing Countries', Paper presented at a workshop on the Future of Partnership Between the ACP States and the EU organized by the Foundation for Globalization Dialogue and The Friedrich Ebert Foundation, with the Development Bank of South Africa. Pretoria. 
Kegley, Charles W. with Eugene R. Wittkopft, 2006, World Politics: Trends and Transformation, Australia, Canada, Mexico, Singapore, Spain, United Kingdom, and United States, Thomson Wadsworth.

Kohli, Ritu, 1995, Kautilya's Political Theory: Yogakshema - the Concept of Welfare State. Foreword by Professor M.M. Sankhdher, Rajouri Garder, New Delhi: Deep and Deep Publications.

Krasner, Stephen, 2001, 'Sovereignty,' Foreign Policy Magazine (January/February).

Lijphart, A., 1984. Democracies: Patterns of Majoritarian and Consensus Government in Twenty-One Democracies, New Haven: Yale University Press.

Lumumba-Kasongo, Tukumbi, 1998, The Rise of Multipartyism and Democracy in the Context of Global Change: The Case of Africa, Westport, CT: Praeger.

Lumumba-Kasongo, Tukumbi, 2000, 'Special Issue: Dynamics and Policy Implications of the Global Reforms at the End of the Second Millennium: A Comparative Perspective', International Journal of Comparative Sociology, Volume XLI, Number 1 .

Lumumba-Kasongo, Tukumbi, 2002, 'Reflections on Liberal Democracy and International Debt Issues in Post-Cold War Africa', Paper Presented at the 10th General Assembly of CODESRIA held in Kampala on December 8-12.

Lumumba-Kasongo, Tukumbi, 2005, Who and What Govern in the World of the States?: A Comparative Study of Constitutions, Citizenry, Power, and Ideology in Contemporary Politics, Lanham, MD: University Press of America.

Lumumba-Kasongo, Tukumbi, 2006, 'Liberal Democracy and Its Critics in Africa', Keynote Speech presented in the Series of Debates Shaping New Africa, organised by the National Committee for International Cooperation and Sustainable Development (NCDO), Amsterdam, the Netherlands, January 10-15.

Lumumba-Kasongo, Tukumbi, 2007, 'Africa's Third-Term Syndrome: A Trend Toward Authoritarianism or a Unique Form of Democracy,?' Georgetown Journal of International Affairs, Volume VIII, Number 1(Winter/Spring).

Newman, Michael, 1996, Democracy, Sovereignty, and the European Union, New York: St. Martin's Press.

Ninsin, K.A., 1998, 'Globalization and Informalization: The Implications for African Politics', The Journal of Comparative Education and International Relations in Africa, Volume 1. No. 2.

Organization for Economic Co-operation and Development (OECD), 2001, The Well-being of Nations: The Role of Human and Social Capital, OECD: Paris.

Primo, Natasha, and Viviene Taylor, 1999, Beyond the DAWN-Africa Debates: Globalization in Search of Alternatives, Cape Town: SADEP, University of Cape Town.

Rawls, John, 1971, A Theory of Justice, Cambridge, MA: Belknap Press of Harvard University.

Sankhdher, M.M. and Maurice Cranston, 1985, The Welfare State, Rajouri Garden, New Delhi: Deep and Deep Publications.

Staedter, Tracy, 2005, 'MIT Plans \$100 Laptop,' Discovery News (May 25).

Stephen, Ellis, 2005, 'How to Rebuild Africa', Foreign Affairs, Vol. 84, No. 5 (September/October). 
UNCTAD, 1998, United Nations Conference on Trade and Development Series, Volume IV, Geneva: UNCTAD.

Yearbook of International Organizations, 1994/95, 'International Organizations by type', Year Book International Organization, 1994/95 Edition.

Windschuttle, Keith, 1999, 'Liberalism and Imperialism,' in Hilton Kramer and Roger Kimball, The Betrayal of Liberalism: How the Disciplines of Freedom and Equality Helped Foster the Illiberal Politics of Coercion and Control, Chicago, Ivan R. Dee.

Wolfe, Alan, 1989, Whose Keeper?: Social Science and Moral Obligation, CA: Berkeley, University of California Press.

World Watch Institute, 2004, Focus: The Consumer Society, State of the World, New York: W.W. Norton and Company, Inc.

World Bank, 2004, Population Data Sheet 1999-2003, Washington DC: Population Reference Bureau, World Bank. 